\title{
Underuse of stopover site by migratory swans
}

\author{
Bart A. Nolet · Abel Gyimesi
}

Received: 15 May 2012/Revised: 2 January 2013/Accepted: 21 January 2013/Published online: 7 February 2013

(C) The Author(s) 2013. This article is published with open access at Springerlink.com

\begin{abstract}
Many migratory birds use a chain of stopover sites to fuel their migration. Under time-minimizing migration, fuelling time and giving-up density at stopovers are predicted to depend on fuelling conditions. Fluctuations in food accessibility likely lead to changes in fuelling conditions, which should in turn be reflected in fuelling time and giving-up density. During their migration, Bewick's Swans Cygnus columbianus bewickii refuel on belowground tubers of Fennel Pondweed Potamogeton pectinatus in shallow lakes. We studied giving-up density and stopover use (expressed in bird-days) of Bewick's Swans at an autumn stopover site (Lauwersmeer, The Netherlands) during 1995-2008, as dependent on local environmental conditions. High water levels were hypothesized to restrict access to tuber stocks. High water levels at the stopover site were predicted to lead to higher giving-up densities and less bird-days spent at the stopover. Annual variation in givingup densities and number of bird-days was strongly associated with year-to-year differences in initial tuber biomass density and number of days with high water levels. As predicted, giving-up density increased and bird-days decreased with the number of days with high water level. We conclude that, in line with time-minimizing migration, changes in fuelling conditions may lead to underuse of a
\end{abstract}

Communicated by A. Hedenström.

B. A. Nolet $(\square)$

Department of Animal Ecology, Netherlands Institute

of Ecology (NIOO-KNAW), PO Box 50,

$6700 \mathrm{AB}$ Wageningen, The Netherlands

e-mail: b.nolet@nioo.knaw.nl

A. Gyimesi

Department of Bird Ecology, Bureau Waardenburg,

Varkensmarkt 9, 4101 CK Culemborg, The Netherlands stopover site. Underuse of stopovers by migratory birds has been reported before but only in the sense that more food was left at stopover sites than at wintering sites. In contrast, in our case, dealing with a given stopover site, more food is left behind in some years than in other years.

Keywords Bewick's Swan - Food availability . Migratory fuelling · Time-minimizing migration . Staging site $\cdot$ Water level

\section{Zusammenfassung}

\section{Unternutzung eines Rastplatzes durch Schwäne}

Viele Zugvögel nutzen aufeinanderfolgende Rastplätze, um Energie für ihren Zug aufzunehmen. Um die Zugdauer zu minimieren, sollte deshalb die „Auftankzeit“ und die Nahrungsdichte beim Verlassen eines Rastplatzes (,Aufgabedichte") von den örtlichen Auftank-Bedingungen abhängen. Fluktuationen in der Nahrungserreichbarkeit können zu Änderungen in diesen Auftankbedingungen führen und sollten sich in Auftankzeit und Aufgabedichte niederschlagen. Singschwäne Cygnus columbianus bewickii ernähren sich während ihres Zuges von Wurzelknollen des Kammlaichkrauts Potamogeton pectinatus im Flachwasserbereich. Wir untersuchten die Nahrungsaufgabedichte un die Rastplaztnutzung (gemessen in Vogel-Tagen) von Singschwänen und deren Abhängigkeit von den lokalen Umweltbedingungen an einem Herbstrastplatz in den Jahren 1995-2008. Hohe Wasserstände sollten den Zugang zu den Wurzelknollen begrenzen und damit zu höheren Nahrungsaufgabedichten und einer geringeren Anzahl an Vogel-Tagen auf diesem Rastplatz führen. Die jährlichen Variationen in den Nahrungsaufgabedichten und den Anzahlen an Vogeltagen waren stark mit Unterschieden in der 
Wurzelknollendichte bei Ankunft am Rastplatz sowie der Anzahl der Tage mit hohen Wasserständen verbunden. Mit der Anzahl an Hochwassertagen erhöhte sich, wie erwartet, die Nahrungsaufgabedichte und verringerte sich die Anzahl der Vogeltage. In Übereinstimmung mit den Vorhersagen zur Minimierung der Zugdauer schlussfolgern wir, dass Änderungen in den Auftankbedingungen zu einer Unternutzung von Rastplätzen führen können. Solche Unternutzungen von Rastplätzen waren zwar bereits berichtet worden, doch nur insofern, dass an den Rastplätzen mehr Nahrung zurückblieb als an den Winterplätzen. Wir dagegen zeigen, dass die nicht genutzte Nahrung innerhalb eines Rastplatzes von Jahr zu Jahr schwanken kann.

\section{Introduction}

Many migratory birds use stopover sites where they fuel for migration (Alerstam and Hedenström 1998). During migration, more time is commonly spent on stopovers than travelling, particularly in birds using flapping flight (Hedenström and Alerstam 1997). Hence, stopover duration largely determines migration speed.

Theory predicts that time-minimizing migrants should stay at a stopover as long as the rate of increase in body fuel enables a faster migration than the overall migration speed on their journey (Alerstam 1991; Alerstam and Lindström 1990). In flying animals, fuel load comes with a flight cost (Pennycuick 1975; Kvist et al. 2001), and therefore potential flight range, and hence migration speed, is expected to increase at a decelerating rate with fuel load (Alerstam 1991; Alerstam and Lindström 1990). Because fuel load is supposed to increase with fuelling time, diminishing returns of potential flight range are expected with increasing fuelling time (Alerstam and Hedenström 1998). At the stopover, carrying and maintaining a given fuel load already comes at a cost, and this will further slow down the increase in flight range with fuelling time (Klaassen and Lindström 1996). Moreover, food depletion might cause diminishing returns of potential flight range with fuelling time, because depletion often leads to lower fuelling rates (Nolet and Drent 1998; but see Lourenço et al. 2010). Together, fuel load and food depletion determine the optimal fuelling time at a stopover (Alerstam and Lindström 1990; Alerstam 1991). If conditions are unfavourable at a particular stopover site, migrants have been shown to move on (Newton 2006, and references therein) and to depart with low fuel loads, as expected when migrants aim to migrate as fast as possible (Lindström and Alerstam 1992).

The main factors determining the fuelling conditions (and hence fuelling time or stopover duration) of a stopover site are its food abundance (Newton 2006), the costs of harvesting that food (Van Eerden et al. 1997b) and food accessibility (Zwarts et al. 1992). Predation risk also affects site use, in particular for small to medium-sized birds, and is often traded-off against food availability (Clark and Butler 1999; Guillemain et al. 2007; Pomeroy et al. 2006; Duijns et al. 2009; Cresswell 1994). These are also the factors known to affect giving-up densities (GUDs), i.e., the food densities remaining after animals have left a food patch (Brown 1988; Nolet et al. 2006a). Hence, GUDs at a stopover site have been proposed to reflect the long-term fuelling rates along the migration route (Van Gils and Tijsen 2007).

Bewick's Swans Cygnus columbianus bewickii (Yarrell) fuel their migration by feeding on aquatic macrophytes, especially tubers of Fennel Pondweed Potamogeton pectinatus (Beekman et al. 1991; Nolet et al. 2001a, b). During aquatic foraging of these large birds (c. $6.0 \mathrm{~kg}$ ), predation risk can be neglected, which partly explains why they prefer to forage on water over field feeding (Nolet et al. 2002). For instance, the largest avian predator in their aquatic habitat, the White-tailed Eagle Haliaeetus albicilla, only exceptionally takes birds of more than $2.5 \mathrm{~kg}$ (Cramp and Simmons 1979). Therefore, aquatically foraging Bewick's Swans are well suited to study the effects of fuelling conditions on stopover use without the confounding effects of predation risk.

In waterbirds, fuelling conditions may be affected by water depth (De Leeuw et al. 1998; Lovvorn 1994; Guillemain et al. 2000; Gawlik 2002). In Lauwersmeer, an important autumn staging site of Bewick's Swans in the Netherlands, within-year (i.e., spatial) variation in GUD was related to water depth (Nolet et al. 2001b), largely due to differences in food accessibility and to a much lesser extent by differences in foraging costs (Nolet et al. 2006a). Because accessibility is directly influenced by water levels, we hypothesize that inter-annual (i.e., temporal) variation in GUD at the stopover site is related to yearly differences in initial food density and water level. As the difference between initial and final biomass represents the biomass consumed by swans (Nolet et al. 2006b), both the initial food density and water levels should also influence stopover duration (at the individual or population level). Hence, we predict that lower food accessibility leads to shorter stopover duration and higher GUDs (Fig. 1). Effectively, this would result in the underuse of the stopover site in some years, in the sense that food is left unexploited, because it was (temporarily) inaccessible.

\section{Methods}

Study area

Lauwersmeer is a shallow freshwater lake $(2,400$ ha, water volume $0.05 \mathrm{~km}^{3}$ ) formed by damming of a bay of the 


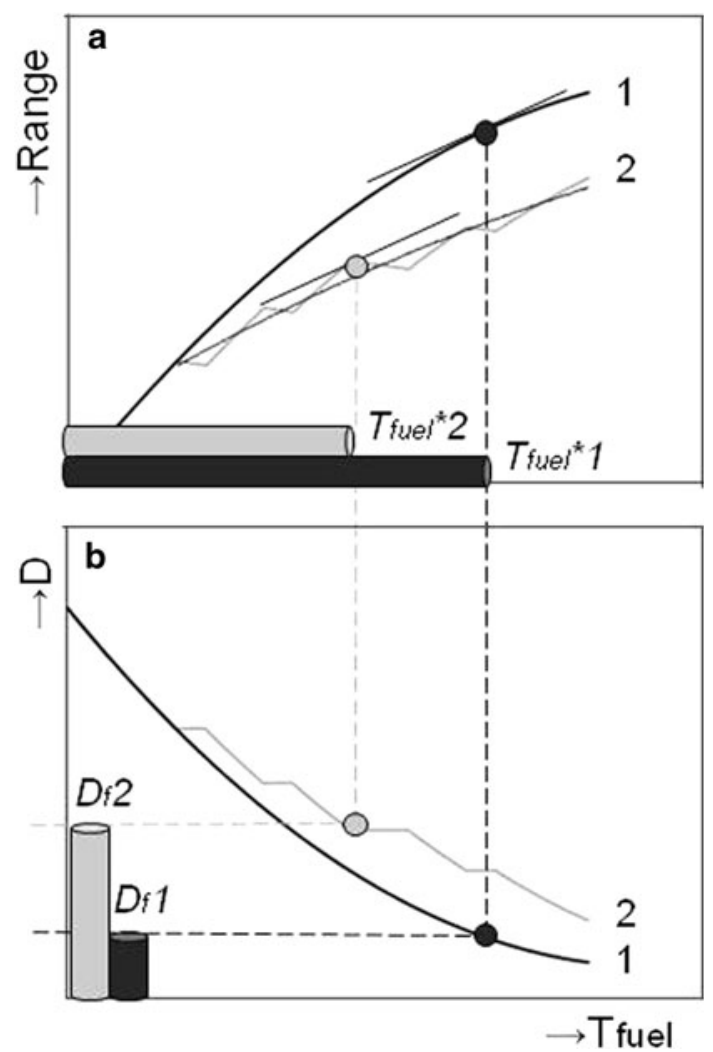

Fig. 1 Optimal fuelling time at a stopover and corresponding givingup density according to optimal bird migration theory. a In migratory birds, potential flight range to the next stopover is expected to increase with fuelling time (Tfuel) at the current stopover, but with diminishing returns (see text). Birds are expected to leave a stopover site when the marginal value (tangents) of flight range on fuelling time falls to their expectation for the whole migration (indicated by dots). A reduction in fuelling conditions leads to a slower increase in flight range (grey curve), and hence an earlier departure. Optimal stopover duration (Tfuel ${ }^{*}$ ) is predicted to be longer under standard ( 1 horizontal black bar) than under reduced ( 2 grey) fuelling conditions. b Due to depletion, food density $(D)$ at the stopover is expected to decrease with fuelling time (Tfuel), at an increasing rate when more birds settle at the stopover site. A reduction in fuelling conditions leads to a lower depletion rate (grey curve) and a higher giving-up density $\left(D_{\mathrm{f}} ; 2\right.$ grey vertical bar) than under standard conditions (1 black bar)

Wadden Sea in 1969, and recharged by two small rivers. Water levels are strictly regulated, although rapid changes in water level can occur, depending on rainfall, wind direction and state of the tide in the Wadden Sea (determining whether water can be sluiced). Our study site was an inlet (Babbelaar) closed to the public.

\section{Tuber sampling}

Tubers were sampled along the north-east shore $\left(53^{\circ} 20^{\prime} 27^{\prime \prime} \mathrm{N}\right.$, $\left.6^{\circ} 13^{\prime} 43^{\prime \prime} \mathrm{E}\right)$ of the inlet between 1995 and 2008. Initially (1995-1998), we sampled in three $20 \times 20 \mathrm{~m}$ plots $100 \mathrm{~m}$ apart (plots 11-13 in fig. 1 of Nolet et al. 2001b). In 1995, we took 18 sediment cores per plot (54 cores in total), but in 1996-1998 we doubled this number (i.e., 36 cores per plot, 108 in total). In later years (2001-2008), we sampled the same area in a grid of $200 \times 40 \mathrm{~m}$ with $1-\mathrm{m}^{2}$ sampling points $20 \mathrm{~m}$ apart, taking 12 cores per point ( 396 cores in total). The $20-\mathrm{m}$ distance between sampling points was sufficient to prevent spatial autocorrelation (Nolet and Mooij 2002). Cores were $10 \mathrm{~cm}$ in diameter and $>30 \mathrm{~cm}$ deep. These were washed over a 3-mm sieve to collect the tubers, which were taken to the laboratory, dried for $48 \mathrm{~h}$ at $70{ }^{\circ} \mathrm{C}$, and weighed (all weights refer to dry weight).

Samples were taken in late September or early October, just before the swans arrived, to assess initial tuber biomass density $D_{\mathrm{i}}$. After the swans had left, usually by midNovember, samples were taken to assess the giving-up tuber biomass density $D_{\mathrm{f}}$. In March, shortly before sprouting of the tubers, samples were taken to determine the tuber biomass density left after the winter $D_{\mathrm{s}}$. Sampling plots and points were marked with small bamboo sticks $10 \mathrm{~cm}$ above the sediment, well below the water surface, to enable re-sampling at the same locations. From 2001 onwards, we sampled the same exact $1 \mathrm{~m}^{2}$, so for these years we corrected the initial tuber density by subtracting the sampled area $\left(12 \pi 0.05^{2} \mathrm{~m}^{2}\right.$; i.e., close to $10 \%$ of plot area) times $D_{\text {i }}$ (i.e., $D_{\text {ic }}=0.91 D_{\mathrm{i}}$ ). In the earlier years, sampled area was $<1 \%$ of plot area, and such a correction was ignored.

\section{Swan observations}

With the aid of $20-60 \times$ telescopes, Bewick's Swans in the inlet were counted daily from the day the first swans arrived until they had all switched to surrounding arable fields or continued southward migration. Daily numbers were summed to obtain the number of swan-days, $S$, per year, linearly interpolating numbers on missing days (comprising $8.6 \%$ of the total $S$ ).

\section{Water levels}

Water levels in Lauwersmeer, obtained from Waterschap Noorderzijlvest, were expressed relative to the Dutch standard (NAP). Daily mean water levels measured at two stations (Zoutkamp, $53^{\circ} 20^{\prime} 14^{\prime \prime} \mathrm{N}, 6^{\circ} 17^{\prime} 49^{\prime \prime} \mathrm{E}$; Nieuwe Robbengat, $\left.53^{\circ} 23^{\prime} 28^{\prime \prime} \mathrm{N}, 6^{\circ} 14^{\prime} 12^{\prime \prime} \mathrm{E}\right)$ either side of the Babbelaar were averaged. The distribution of average daily water levels in October-November was right skewed (Fig. 2; Skew $=1.81 \pm 0.08$ SE, Shapiro-Wilk $W=$ $0.805, P<0.001)$, reflecting rapid peaks in water level rise. Rather than using average daily water level, we calculated the number of days with "high" water levels $h$ (i.e., higher than the critical water level) as our independent variable. As the critical water level, we took the mean of 


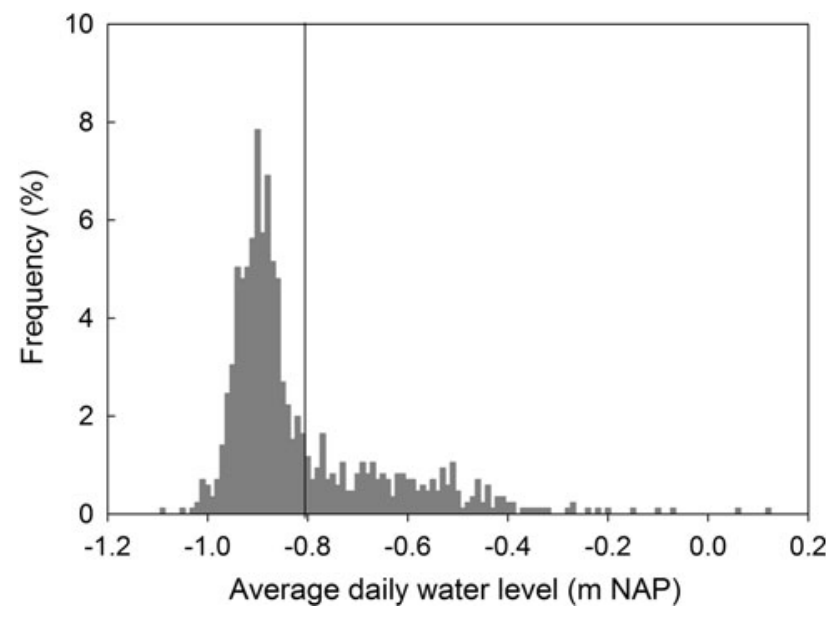

Fig. 2 Frequency distribution of daily water level in Lauwersmeer (average of two stations) in October-November 1995-2008 $(n=854)$; water level aimed for by the water board is $-0.93 \mathrm{~m}$ NAP $($ NAP $=$ Amsterdam Ordnance Datum, data Waterschap Noorderzijlvest). Vertical line indicates mean value of $-0.81 \mathrm{~m}$ NAP

the observed water levels $(-0.81 \mathrm{~m} \mathrm{NAP})$, but any critical level between -0.83 and $-0.68 \mathrm{~m}$ NAP yielded similar results (not shown).

\section{Statistics}

Variables were tested for normality with Shapiro-Wilk $W$ test. We compared 7 models of final tuber density $D_{\mathrm{f}}$ and swan-days $S$, respectively, as functions of initial tuber density $D_{\mathrm{i}}$ (or corrected initial tuber density $D_{\text {ic }}$ in the case of $D_{\mathrm{f}}$ ), days with high water $h$, and their two-way interactions, in all possible combinations. Akaike's information criterion corrected for small sample size was used to select the most parsimonious model in this model set (Burnham and Anderson 2002). Because the order of models is to some extent dependent on the measurement scale of the variables when including an interaction term, we first normalized all variables $x$ to $x_{\text {norm }}\left(0 \leq x_{\text {norm }} \leq 1\right)$ by taking $x_{\text {norm }}=\left(x-x_{\min }\right) /\left(x_{\max }-x_{\min }\right)$, where $x_{\min }$ and $x_{\max }$ are the minimum and maximum values of a variable, respectively. We regarded $D_{\mathrm{f}}$ to be a function of local $D_{\mathrm{i}}$, hence our choice for $D_{\text {ic }}$ when modelling $D_{\mathrm{f}} . S$, however, was regarded to be a function of a more global $D_{\mathrm{i}}$.

Swan usage and realized final tuber density were predicted from initial tuber density and days with high (i.e., above-average) water levels as follows. As the functional response is nearly linear (Nolet et al. 2002), the foraging time at $h=0$, indicated by $t(0)$, to deplete a unit area to $D_{\mathrm{f}}(0)$ can be approximated as:

$t(0)=(1 /(a \cdot \varphi)) \cdot \ln \left(D_{\mathrm{i}} / D_{\mathrm{f}}(0)\right)$,

where $a$ is the attack rate, and $\varphi$ is the proportion of foraging time spent feeding (feeding by head-dipping or up-ending is part of foraging which also includes digging and breathing pauses). As values, we took the average for sandy and clayey sediments, as both occur in the inlet, giving $\varphi=0.74$ and $a=0.00082 \mathrm{~m}^{2} / \mathrm{s}$ (Nolet and Klaassen 2009). We assumed that the effective foraging time linearly decreases with the number of days with above average water levels $(0 \leq h \leq 61)$ :

$t(h)=t(0)-h / 61 \times t(0)$

The number of swan-days at $h$ days with above average water levels $S(h)$ is then:

$S(h)=(t(h) \cdot A) /(24 \times 60 \times 60)$,

where $A$ is the area of pondweed in the inlet $\left(17.7 \times 10^{4} \mathrm{~m}^{2}\right)$ (Nolet et al. 2006b). Realized final tuber density $D_{\mathrm{f}}(h)$ is obtained after re-arranging:

$t(h)=(1 /(a \cdot \varphi)) \cdot \ln \left(D_{\mathrm{i}} / D_{\mathrm{f}}(h)\right)$,

which yields:

$D_{\mathrm{f}}(h)=\exp \left(\ln D_{\mathrm{i}}-a \cdot \varphi \cdot t(h)\right)$

\section{Results}

In Lauwersmeer, final tuber density $D_{\mathrm{f}}$ increased with the (corrected) initial tuber density $D_{\text {ic }}$ (Table 1, model 3) and number of days with above average water levels $h$ (Table 1, model 2), both variables explaining the final tuber density equally well. The most parsimonious model included both these variables, such that $D_{\mathrm{f}}$ increased with $D_{\text {ic }}$ depending on the number of days with above average water levels $h$ (Fig. 3a). This could explain the exceptionally high $D_{\mathrm{f}}$ in 2006 (highest data point in Fig. 3a), when there were many days of above average water levels in Lauwersmeer $(h=36)$.

There was little difference in empirical support between the two top models predicting swan-days $S$, both including the initial tuber density $D_{\mathrm{i}}$ and the number of days with above average water levels $h$ (Table 2, models 1-2). In general, $S$ increased with $D_{\mathrm{i}}$ and decreased with $h$, and these models only differed in the way the number of days with above average water levels $h$ changed the relationship between $S$ and $D_{\text {i }}$ (i.e., running parallel or divergent; the latter is shown).

Using the experimentally derived functional responses yielded very similar patterns of final tuber density (Fig. 3b) and swan usage (Fig. 4b) as the depicted statistical relationships (Figs. 3a, Fig. 4a).

The reduction in tuber biomass from November to March (17.8 \% $\pm .1 \mathrm{SE}, n=11)$, after the swans had left Lauwersmeer, was not significantly different $\left(t_{10}=-1.85\right.$, $P>0.09)$ from winter mortality without swan grazing (6.5\%, assessed using winter exclosures) (Hidding et al. 
Table 1 Top 3 explanatory models to explain final tuber density $D_{\mathrm{f}}$ in Lauwersmeer in 1995-2008 according to Akaike's information criterion corrected for small sample size (AICc; $n=11$ )

\begin{tabular}{lllllllll}
\hline Model & $K$ & Deviance ratio & $\Delta$ AICc & $L\left(m_{\mathrm{i}} \mid x\right)$ & $w_{i}$ & Evidence ratio & RMSD $\left(\mathrm{g} / \mathrm{m}^{2}\right)$ & $r^{2}$ \\
\hline $1 . \boldsymbol{D}_{\mathbf{i c}} \times \boldsymbol{h}$ & $\mathbf{3}$ & $\mathbf{1 4 . 0}$ & $\mathbf{0 . 0 0}$ & $\mathbf{1 . 0 0}$ & $\mathbf{0 . 5 3}$ & $\mathbf{1 . 0}$ & $\mathbf{3 . 3 8}$ & $\mathbf{0 . 6 1}$ \\
$2 . h$ & 3 & 18.6 & 2.41 & 0.30 & 0.16 & 3.3 & 0.48 \\
$3 . D_{\text {ic }}$ & 3 & 19.7 & 3.05 & 0.22 & 0.11 & 4.6 & 4.02 & 0.45 \\
\hline
\end{tabular}

Each model is defined by the listed independent variables: corrected initial tuber density $D_{\text {ic }}$, number of days with above-average water levels $h$, and possible interaction terms $(\times)$. All models with substantial empirical support (i.e., $\triangle \mathrm{AICc}<2$ ) are indicated in bold; $K$ is the number of parameters, $L\left(m_{\mathrm{i}} \mid x\right)$ is likelihood of model $i$ given the data, and $w_{\mathrm{i}}$ is its Akaike's weight (Burnham and Anderson 2002). RMSD is the root mean squared deviation of observed on predicted values of (in this case) $D_{\mathrm{f}}$, and $r^{2}$ the coefficient of determination (i.e., proportion of the variation in observed values explained by the predicted values of, in this case, $D_{\mathrm{f}}$ )

2012) (Fig. 5). Only in 1996 was a relatively large reduction $(63 \%)$ measured (Fig. 5; light grey point well below the line).

\section{Discussion}

Swans left more tuber biomass at the stopover site when more days with high water levels occurred. In a previous analysis, the positive relationship between initial $\left(D_{\mathrm{i}}\right)$ and final $\left(D_{\mathrm{f}}\right)$ tuber densities was ascribed to part of the initial tuber biomass being buried deep, inaccessible to the swans, and the slope of the regression of $D_{\mathrm{f}}$ on $D_{\mathrm{i}}$ was interpreted as the fraction out of reach of the swans (Nolet et al. 2006b). The current analysis suggests that this positive relationship results from periods with high water, which implies that the final tuber density in Lauwersmeer would be similar in all years, independent of initial tuber density, if water levels would remain low throughout the stopover period.

When considering swan-days $S$, two models were equally well supported by the data. According to both these models, $S$ increased with initial tuber density $D_{\mathrm{i}}$, but for a given $D_{\mathrm{i}}$, swan use was lower when more days with high water levels occurred (i.e., large $h$ ). We chose to depict the second most parsimonious model (Fig. 4a), because it was biologically the most plausible (the most parsimonious model predicted $S>0$ at $D_{\mathrm{i}}<0$ ), and because it was in line with the most parsimonious model for $D_{\mathrm{f}}$. This can be seen by writing model 1 in Table 1 as $D_{\mathrm{f}}=b_{0}+b_{2} \times$ $D_{\text {ic }} \times h$, and express it as consumption $C=D_{\text {ic }}-D_{\mathrm{f}}=$ $D_{\text {ic }}-\left(b_{0}+b_{2} \times D_{\text {ic }} \times h\right)=-b_{0}+D_{\text {ic }}-b_{2} \times D_{\text {ic }} \times h$. This is very similar in structure as model 2 in Table 2 : $S=b_{0}+b_{1} \times D_{\text {ic }}+b_{2} \times D_{\text {ic }} \times h$.

The results of the analyses of final tuber density and swan-days were therefore in line with each other, and suggest that swans left Lauwersmeer earlier when they encountered high water, leading to an underuse of the stopover site.
The high water levels reduce food accessibility and hence fuelling rate, and induce the birds to continue migration, in accordance with the hypothesis of timeminimizing migration. The reduction in tuber biomass from November to March was as expected from winter mortality from other causes than swan predation, as measured in winter exclosures, confirming that there was no measurable swan foraging after our final sampling in November. Only in 1996 did the relatively large reduction in tuber biomass between November and March of the following calendar year suggest that the swans returned to forage on the lake when water level had returned to normal. This may be because in that year the water levels dropped to normal again relatively early in autumn (on 9 November 1996, only 2 days after our final sampling, 5,000 Bewick's Swans were counted in Lauwersmeer, http://www.waarneming.nl ). In a way, this exception proves our concept of underuse, because apparently there was food left to be used by swans.

Tuber loss due to other causes than swan predation is small over the short exploitation period ( $3 \%$ per month in winter exclosures; Hidding et al. 2009). Hence, the difference between the initial and final tuber density should roughly equal the consumption $C$ by the swans, and the observed patterns of depletion and stopover duration should be reproducible from the functional response of swans feeding on tubers (Nolet et al. 2006b). This functional response model indeed yields very similar patterns as the statistical models, both for $D_{\mathrm{f}}$ (cf. Fig. 3a, b) and for $S$ (cf. Fig. 4a, b). Apparently, local environmental conditions (initial tuber density $D_{\mathrm{i}}$ and days with above average water levels $h$ ) largely explain the annual variation in final tuber density $D_{\mathrm{f}}$ and swan-days $S$.

A rise in bird-days can be due to more birds stopping over at the site or to an increase in stopover duration of individual birds. Whereas there are some indications that staging numbers vary annually with food density at a stopover site (Van Gils et al. 2005), evidence for longer stopover durations at the individual level when resources are plentiful is scarce. In fact, in hummingbirds, the 


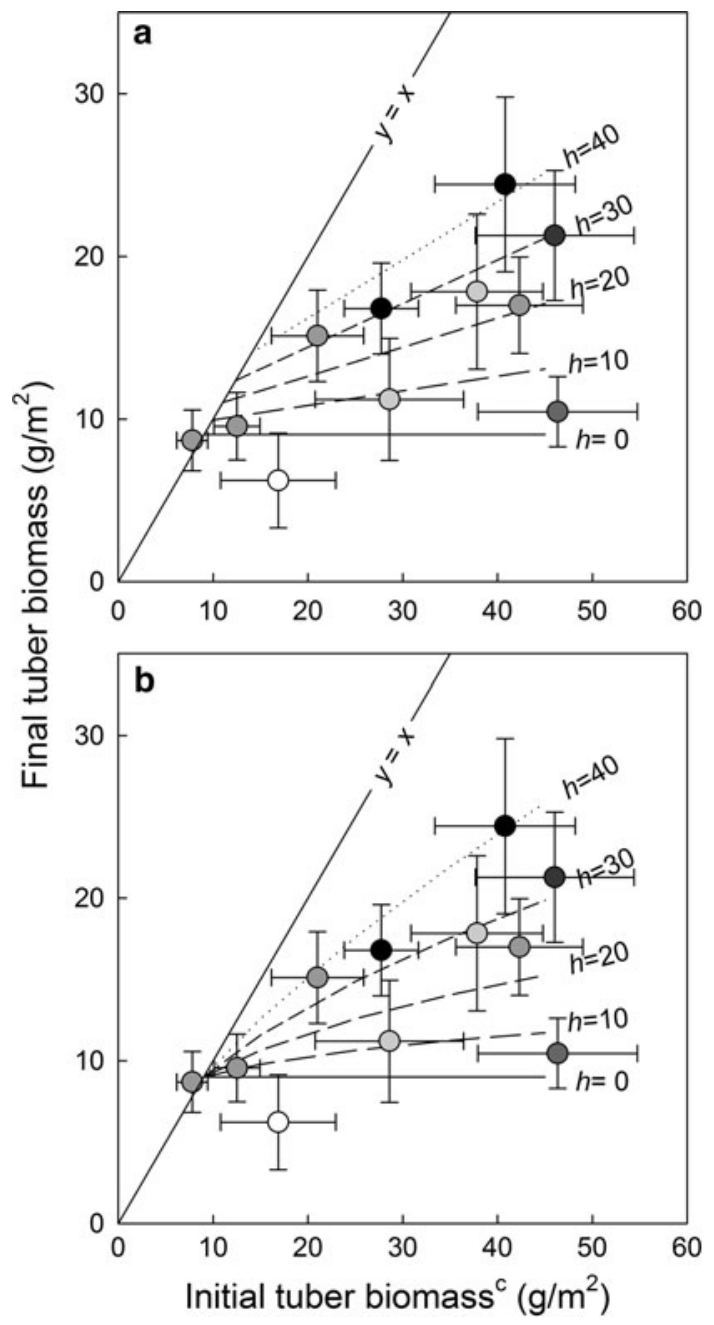

Fig. 3 Final tuber biomass density $D_{\mathrm{f}}$ as a function of corrected initial tuber biomass density $D_{\text {ic }}$ and the number of days with high water in Lauwersmeer ( $h$, days). Each data point represents 1 year in the period 1995-2008, with grey shading according to $h$ values (from white if $h \leq 6$ to black if $h>30$ ). The difference from a data point to the $y=x$ line along the vertical equals the consumption $\left(\mathrm{g} / \mathrm{m}^{2}\right)$ by swans. Error bars indicate $95 \%$ CI. Lines depict a most parsimonious model with $D_{\text {ic }}$ and $h$ as explanatory variables (model 1 in Table 1); b predictions based on linear functional response (see "Methods" for calculation). When there is no restriction by high water levels $(h=0)$, the best statistical model (Table 1, model 1) predicts a final tuber density $D_{\mathrm{f}}(0)=9.0 \mathrm{~g} / \mathrm{m}^{2}$

opposite pattern was found, with stopover duration decreasing with resource (i.e., flower) density (Russell et al. 1994). On the other hand, when resource conditions

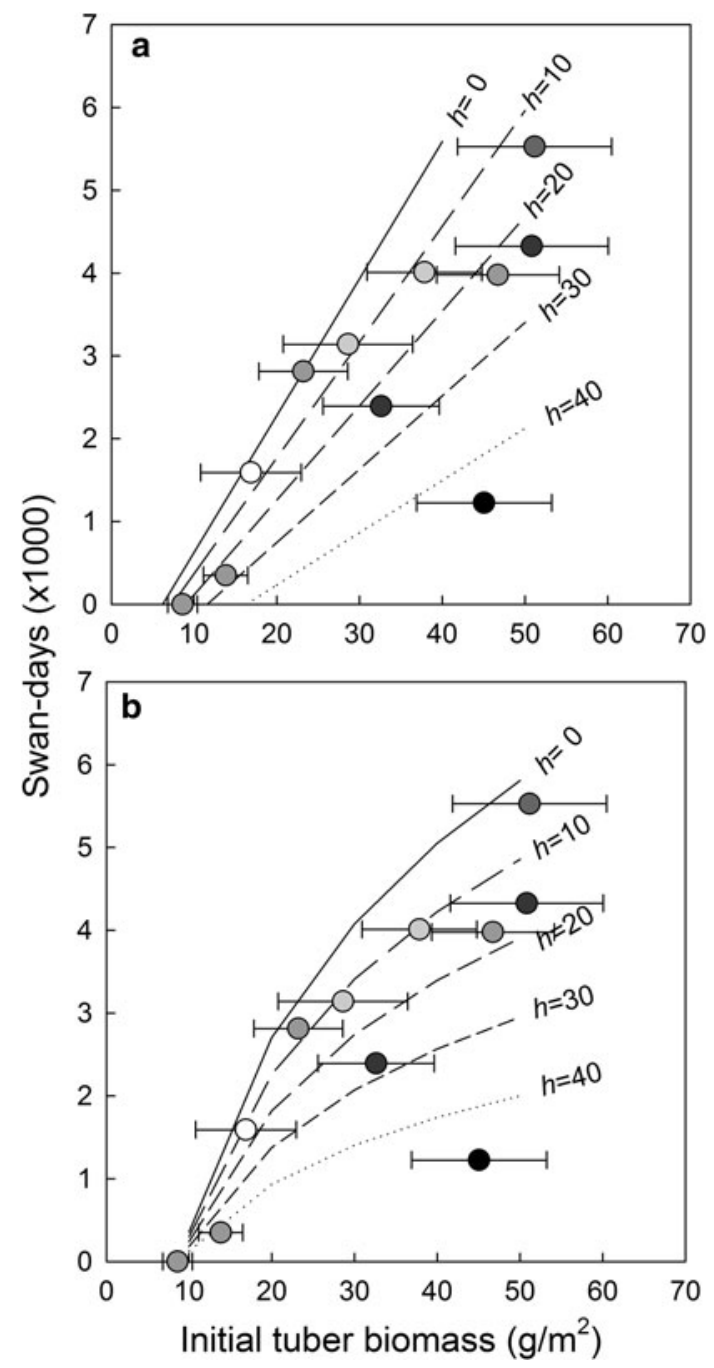

Fig. 4 Swan-days $S$ as a function of initial tuber biomass density $D_{\mathrm{i}}$ and the number of days with high water in Lauwersmeer ( $h$, days). Each data point represents 1 year in the period 1995-2008, with grey shading according to $h$ values (see Fig. 3). Error bars indicate $95 \%$ CI. Lines depict a second most parsimonious model with $D_{\text {ic }}$ and $h$ as explanatory variables (model 2 in Table 2); b predictions based on linear functional response (see Fig. 3 and "Methods" for calculation)

are very poor, birds are found to move on quickly (Newton 2006). Hence, stopover duration may have a humped-shape relationship with resource density: at low resource density, birds leave quickly or skip the site altogether; at intermediate resource density, birds make use of the site but need time to refuel; whereas at high resource density, birds stay

Table 2 Top 3 explanatory models for swan-days $S$ in Lauwersmeer in 1995-2008 according to Akaike's information criterion corrected for small sample size (AICc; $n=11$ ). See also Table 1

\begin{tabular}{|c|c|c|c|c|c|c|c|c|}
\hline Model & $K$ & Deviance ratio & $\Delta \mathrm{AICc}$ & $L\left(m_{\mathrm{i}} \mid x\right)$ & $w_{i}$ & Evidence ratio & $\operatorname{RMSD}\left(\times 10^{3}\right)$ & $r^{2}$ \\
\hline 1. $D_{\mathrm{i}}+h$ & 4 & 0.59 & 0.00 & 1.00 & 0.53 & 1.0 & 0.65 & 0.85 \\
\hline 2. $D_{\mathrm{i}}+D_{\mathrm{i}} \times h$ & 4 & 0.60 & 0.61 & 0.74 & 0.39 & 1.4 & 0.66 & 0.84 \\
\hline 3. $D_{\mathrm{i}}$ & 3 & 1.25 & 4.33 & 0.11 & 0.06 & 8.7 & 1.01 & 0.63 \\
\hline
\end{tabular}




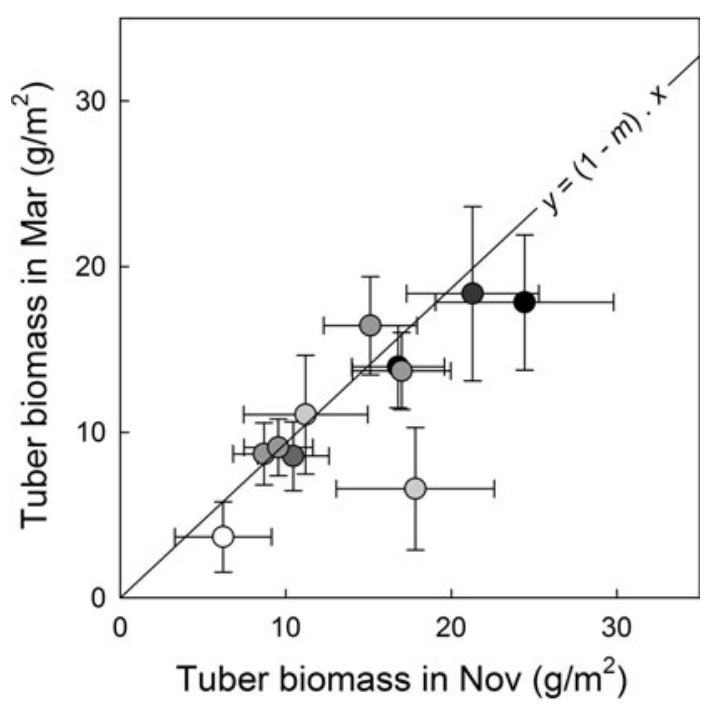

Fig. 5 Final tuber biomass densities in November (after the swans had left the lake) and March of the following calendar year (at the end of the winter). Each point represents 1 year in the period 1995-2008, with grey shading according to $h$ values (see Fig. 3). Error bars indicate $95 \%$ CI. Observed tuber biomass densities in March are generally as expected from the winter mortality $(m)$ measured in winter exclosures (line, see text)

relatively short periods because they are able to rapidly replenish their stores (Schaub et al. 2008). However, birds are predicted to leave a rich site with relatively high fuel loads, which may extend the fuelling period at rich resource densities despite the more rapid fuelling (Lindström and Alerstam 1992; Klaassen and Lindström 1996). So, the increase in swan-days with resource availability is possibly a combination of more swans stopping over and a net increase in stopover duration per swan. Unfortunately, too few marked swans were available to estimate turnover, especially in the later years, to distinguish between these two possibilities.

A carry-over effect may cause individuals to stage longer at a site when conditions at the previous site were poor (Bauer et al. 2006). Lower fuelling rates are predicted to lead to lower departure fuel loads (Lindström and Alerstam 1992). Therefore, birds are predicted to arrive relatively lean to a next stopover site, which may cause the birds to stay longer there and, in case of depletable resources, deplete these further. Some studies indeed have shown that lean arriving migrants generally stayed longer than fat ones (Cherry 1982; Bairlein 1985; Biebach et al. 1986; Moore and Kerlinger 1987; Goymann et al. 2010), or that stopover duration was longer when in a given year body condition at arrival at the stopover site was low (Russell et al. 1994). However, some other studies have found no consistent relationship between arrival condition and stopover duration (Safriel and Lavee 1988; Butler et al. 1997; Skagen and Knopf
1994; Lyons and Haig 1995; Holmgren et al. 1993), possibly because departure was triggered more by time schedules or flight conditions (e.g. favourable weather) than by fuelling conditions. The large variation in giving -up tuber densities and swan-days explained by local effects of food density and accessibility, as well as the close fit with the functional response model, suggests that such carry-over effects were small in comparison to local effects.

Our study provides clear evidence for underuse of a stopover site, in line with time-minimizing migration. Underuse of stopovers has been reported before, but in those cases it was used in the sense that migratory birds leave more food at stopover sites than at wintering sites because on the latter they should reflect energy balance rather than a positive energy budget (Van Eerden et al. 1997a; but see Lourenço et al. 2010; Alonso et al. 1994). Here, we show that migratory birds may also underuse a stopover site in the sense that they leave more food behind in some years than in others, because of yearly differences in fuelling conditions.

Acknowledgments Thanks to all who assisted during 15 years of field work, especially: Thijs de Boer, Ten Dekkers, Marcel Klaassen, Raymond Klaassen, Oscar Langevoord, Koos Swart, Peter de Vries, and Erik Wessel. We were introduced to the study system by Jan Beekman, Mennobart van Eerden and the late Rudi Drent. Thanks to Jan Willems (Staatsbosbeheer) for permission to work in the nature reserve, and Waterschap Noorderzijlvest for water level data. Phil Battley, Silke Bauer, Matthieu Guillemain, Anders Hedenström, Raymond Klaassen, Ruedi Nager and Jan van Gils commented on drafts of the manuscript. A.Gy. was supported by the Netherlands Organisation for Scientific Research (NWO grant 814.01.008 to BAN). This is publication 5400 of the Netherlands Institute of Ecology.

Open Access This article is distributed under the terms of the Creative Commons Attribution License which permits any use, distribution, and reproduction in any medium, provided the original author(s) and the source are credited.

\section{References}

Alerstam T (1991) Bird flight and optimal migration. Trends Ecol Evol 6:210-215

Alerstam T, Hedenström A (1998) The development of bird migration theory. J Avian Biol 29:343-369

Alerstam T, Lindström Å (1990) Optimal bird migration: the relative importance of time, energy, and safety. In: Gwinner E (ed) Bird migration: physiology and eco-physiology. Springer, Berlin, pp 331-351

Alonso JC, Alonso JA, Bautista LM (1994) Carrying capacity of staging areas and facultative migration extension in common cranes. J Appl Ecol 31:212-222

Bairlein F (1985) Body weights and fat deposition of Palaearctic passerine migrants in the central Sahara. Oecologia 66:141-146

Bauer S, Madsen J, Klaassen M (2006) Intake rates, stochasticity, or onset of spring - what aspects of food availability affect spring 
migration patterns in Pink-footed Geese Anser brachyrhynchus? Ardea 94:555-566

Beekman JH, Van Eerden MR, Dirksen S (1991) Bewick's Swans Cygnus columbianus bewickii utilising the changing resource of Potamogeton pectinatus during autumn in the Netherlands. Wildfowl (Suppl 1):238-248

Biebach H, Friedrich W, Heine G (1986) Interaction of bodymass, fat, foraging and stopover period in trans-sahara migrating passerine birds. Oecologia 69:370-379

Brown JS (1988) Patch use as an indicator of habitat preference, predation risk, and competition. Behav Ecol Sociobiol 22:37-47

Burnham KP, Anderson DR (2002) Model selection and multimodel inference: a practical information-theoretic approach, 2nd edn. Springer, New York

Butler RW, Williams TD, Warnock N, Bishop MA (1997) Wind assistance: a requirement for migration of shorebirds? Auk 114:456-466

Cherry JD (1982) Fat deposition and length of stopover of migrant White-crowned Sparrows. Auk 99:725-732

Clark CW, Butler RW (1999) Fitness components of avian migration: a dynamic model of Western Sandpiper migration. Evol Ecol Res 1:443-457

Cramp S, Simmons KEL (1979) The birds of the Western Palearctic, vol II. Oxford University Press, Oxford

Cresswell W (1994) Age-dependent choice of redshank (Tringa totanus) feeding location-profitability or risk. J Anim Ecol 63:589-600

De Leeuw JJ, Butler PJ, Woakes AJ, Zegwaard F (1998) Body cooling and its energetic implications for feeding and diving of tufted ducks. Physiol Zool 71:720-730

Duijns S, van Dijk JGB, Spaans B, Jukema J, de Boer WF, Piersma T (2009) Foraging site selection of two subspecies of Bar-tailed Godwit Limosa lapponica: time minimizers accept greater predation danger than energy minimizers. Ardea 97:51-59

Gawlik DE (2002) The effects of prey availability on the numerical response of wading birds. Ecol Monogr 72:329-346

Goymann W, Spina F, Ferri A, Fusani L (2010) Body fat influences departure from stopover sites in migratory birds: evidence from whole-island telemetry. Biol Lett 6:478-481

Guillemain M, Fritz H, Blais S (2000) Foraging methods can affect patch choice: an experimental study in Mallard (Anas platyrhynchos). Behav Process 50:123-129

Guillemain M, Arzel C, Legagneux P, Elmberg J, Fritz H, Lepley M, Pin C, Arnaud A, Massez G (2007) Predation risk constrains the plasticity of foraging behaviour in teals, Anas crecca: a flywaylevel circumannual approach. Anim Behav 73:845-854

Hedenström A, Alerstam T (1997) Optimum fuel loads in migratory birds: distinguishing between time and energy minimization. J Theor Biol 189:227-234

Hidding B, Nolet BA, de Boer T, de Vries PP, Klaassen M (2009) Compensatory growth in an aquatic plant mediates exploitative competition between seasonally tied herbivores. Ecology 90:1891-1899

Hidding B, Klaassen M, de Boer T, de Vries PP, Nolet BA (2012) Aquatic plant shows flexible avoidance by escape from tuber predation by swans. Basic Appl Ecol 13:50-58

Holmgren N, Ellegren H, Pettersson J (1993) Stopover length, body mass and fuel deposition rate in autumn migrating adult Dunlins Calidris alpina: evaluating the effects of moulting status and age. Ardea 81:9-20

Klaassen M, Lindström A (1996) Departure fuel loads in timeminimizing migrating birds can be explained by the energy costs of being heavy. J Theor Biol 183:29-34

Kvist A, Lindström Å, Green M, Piersma T, Visser GH (2001) Carrying large fuel loads during sustained bird flight is cheaper than expected. Nature 413:730-732
Lindström ̊, Alerstam T (1992) Optimal fat loads in migrating birds: a test of the time-minimization hypothesis. Am Nat 140:477-491

Lourenço PM, Mandema FS, Hooijmeijer JCEW, Granadeiro JP, Piersma T (2010) Site selection and resource depletion in blacktailed godwits Limosa 1. limosa eating rice during northward migration. J Anim Ecol 79:522-528

Lovvorn JR (1994) Biomechanics and foraging profitability: an approach to assessing trophic needs and impacts of diving ducks. Hydrobiologia 279(280):223-233

Lyons JE, Haig SM (1995) Fat content and stopover ecology of spring migrant Semipalmated Sandpipers in South Carolina. Condor 97:427-437

Moore F, Kerlinger P (1987) Stopover and fat deposition by North American wood-warblers (Parulinae) following spring migration over the Gulf of Mexico. Oecologia 74:47-54

Newton I (2006) Can conditions experienced during migration limit the population levels of birds? J Ornithol 147:146-166

Nolet BA, Drent RH (1998) Bewick's Swans refuelling on pondweed tubers in the Dvina Bay (White Sea) during their spring migration: first come, first served. J Avian Biol 29:574-581

Nolet BA, Klaassen M (2009) Retrodicting patch use by foraging swans in a heterogeneous environment using a set of functional responses. Oikos 118:431-439

Nolet BA, Mooij WM (2002) Search paths of swans foraging on spatially autocorrelated tubers. J Anim Ecol 71:451-462

Nolet BA, Andreev VA, Clausen P, Poot MJM, Wessel EGJ (2001a) Significance of the White Sea as a stopover for Bewick's Swans Cygnus columbianus bewickii in spring. Ibis 143:63-71

Nolet BA, Langevoord O, Bevan RM, Engelaar KR, Klaassen M, Mulder RJW, Van Dijk S (2001b) Spatial variation in tuber depletion by swans explained by differences in net intake rates. Ecology 82:1655-1667

Nolet BA, Bevan RM, Klaassen M, Langevoord O, Van der Heijden YGJT (2002) Habitat switching by Bewick's swans: maximisation of average long-term energy gain? J Anim Ecol 71:979-993

Nolet BA, Fuld VN, Van Rijswijk MEC (2006a) Foraging costs and accessibility as determinants of giving-up densities in a swanpondweed system. Oikos 112:353-362

Nolet BA, Gyimesi A, Klaassen RHG (2006b) Prediction of bird-day carrying capacity on a staging site: a test of depletion models. J Anim Ecol 75:1285-1292

Pennycuick C (1975) Mechanics of flight. In: Farner DS, King JR (eds) Avian biology, vol 5. Academic, New York, pp 1-75

Pomeroy AC, Butler RW, Ydenberg RC (2006) Experimental evidence that migrants adjust usage at a stopover site to trade off food and danger. Behav Ecol 17:1041-1045

Russell RW, Carpenter FL, Hixon MA, Paton DC (1994) The impact of variation in stopover habitat quality on migrant Rufous Hummingbirds. Conserv Biol 8:483-490

Safriel UN, Lavee D (1988) Weight changes of cross-desert migrants at an oasis-do energetic considerations alone determine the length of stopover? Oecologia 76:611-619

Schaub M, Jenni L, Bairlein F (2008) Fuel stores, fuel accumulation, and the decision to depart from a migration stopover site. Behav Ecol 19:657-666

Skagen SK, Knopf FL (1994) Residency patterns of migrating sandpipers at a midcontinental stopover. Condor 96:949-958

Van Eerden MR, Beekman JH, Smit M, Oosterbeek K (1997a) Patch use by Bewick's Swans Cygnus columbianus bewickii feeding upon Sago Pondweed Potamogeton pectinatus in shallow lakes in the Netherlands: variation in exploitation thresholds caused by social, environmental and time dependent factors. In: Van Eerden MR (ed) Patchwork. Rijkswaterstaat, Directie IJsselmeergebied, Lelystad, pp 187-214

Van Eerden MR, De Leeuw JJ, Slager B, Bij de Vaate A (1997b) A field test of the carrying capacity concept in wintering diving 
ducks: do high foraging costs delimit exploitation of Zebra Mussels? In: Van Eerden MR (ed) Patchwork. Directie IJsselmeergebied, Rijkswaterstaat, Lelystad, pp 283-316

Van Gils JA, Tijsen W (2007) Short-term foraging costs and longterm fueling rates in central-place foraging swans revealed by giving-up exploitation times. Am Nat 169:609-620

Van Gils JA, Dekinga A, Spaans B, Vahl WK, Piersma T (2005) Digestive bottlencks affects foraging decisions in red knots
Calidris canutus. II. Patch choice and length of working day. J Anim Ecol 74:120-130

Zwarts L, Blomert AM, Wanink JH (1992) Annual and seasonal variation in the food supply harvestable by knot Calidris canutus staging in the Wadden Sea in late summer. Mar Ecol Progr Ser 83:129-139 